\title{
Article
}

\section{Detrimental Effect of Ozone on Pathogenic Bacteria}

\author{
Karyne Rangel ${ }^{1 *}$, Fellipe O. Cabral ${ }^{2}$, Guilherme Curty Lechuga ${ }^{1}$, João P. R.S. Carvalho ${ }^{1}$, Maria H.S. Villas-Bôas ${ }^{2}$, \\ Victor Midlej ${ }^{4}$ and Salvatore Giovanni De-Simone ${ }^{1,3, *}$
}

\author{
${ }^{1}$ FIOCRUZ, Center for Technological Development in Health (CDTS)/ National Institute of Science and \\ Technology for Innovation in Neglected Population Diseases (INCT-IDPN), Rio de Janeiro, RJ, 21040-900, \\ Brazil. \\ 2 Microbiology Department, National Institute for Quality Control in Health (INCQS), FIOCRUZ, Rio de \\ Janeiro, RJ, 21040-900, Brazil. \\ ${ }^{3}$ Department of Molecular and Cellular Biology, Biology Institute, Federal Fluminense University, Niterói, RJ, \\ 22040-036, Brazil. \\ ${ }^{4}$ FIOCRUZ, Laboratory of Cellular and Ultrastructure (IOC), Rio de Janeiro, RJ. Brazil. \\ * Correspondence: karynercarvalho@cdts.fiocruz (K.R, +552138658240); dsimone@cdts.fiocruz.br (S.G.D-S \\ +552138658183 )
}

\begin{abstract}
Background: Disinfection of medical devices designed for clinical use associated or not with the growing area of tissue engineering is an urgent need. However, traditional disinfection methods are not always suitable for some biomaterials, especially those sensitive to chemical, thermal, or radiation. Therefore, the objective of this study was to evaluate the minimal concentration of ozone gas $\left(\mathrm{O}_{3}\right)$ necessary to control and kill a set of sensitive or multi-resistant Gram-positive and Gram-negative bacteria. The cell viability, membrane permeability, and the levels of reactive intracellular oxygen (ROS) species were also investigated; (2) Material and Methods: Four standard strains and a clinical MDR strain were exposed to low doses of ozone at different concentrations and times. Bacterial inactivation (cultivability, membrane damage) was investigated using colony counts, resazurin as a metabolic indicator, and propidium iodide (PI). A fluorescent probe ( $\mathrm{H}_{2} \mathrm{DCFDA}$ ) was used for the ROS analyses; (3) Results: No reduction in the count colony was detected after $\mathrm{O}_{3}$ exposure, compared to the control group. However, the cell viability of E. coli (30\%), P. aeruginosa (25\%), and A. baumannii (15\%) was reduced considerably. The bacterial membrane of all strains was not affected by $\mathrm{O}_{3}$ but presented a significant increase of ROS in E. coli $(90 \pm 14 \%)$, P. aeruginosa $(62.5 \pm 19 \%)$, and A. baumanni $(52.6 \pm 5 \%)$; (4) Conclusion: Low doses of ozone were able to interfere in the cell viability of most strains studied, and although it does not cause damage to the bacterial membrane, increased levels of reactive ROS are responsible for causing a detrimental effect in the lipids, proteins, and DNA metabolism.
\end{abstract}

Keywords: ozone; detrimental effect; pathogenic bacteria; antimicrobial resistance; ROS; Acinetobacter baumannii; Pseudomonas aeruginosa;

\section{Introduction}

"Deaf Endemic" "Deaf Endemic" is a term used by the World Health Organization (WHO) as a reference to Health Care-Associated Infections (HAIs) since these are identified as the most frequent adverse effect during health care provision [1]. HAIs comprise any infection acquired after the patient's admission to the hospital, which may occur during hospitalization or shortly after discharge, as long as it is related to hospitalization or the procedures performed during the period $[2,3]$.

The surfaces, equipment, and medical devices in hospitals play an essential role in spreading HAIs, as secondary reservoirs promote cross-contamination [4]. The hands of health professionals correspond to the most common means of transferring pathogens [5]. In intensive care units (ICUs), even after adopting strict cleaning and disinfection protocols, many patients are infected with HAIs [6-8]. These infections are more frequent in these units, where outbreaks usually originate [9] since the use of antibiotics is 
approximately ten times greater than in general hospital wards [10,11]. In addition, HAIs lead to an increase in deaths (morbidity and mortality), favors the development of resistant pathogens, prolong hospital stay, and, consequently, health costs [12-18].

The National Health Security Network of the Centers for Disease Control and Prevention (CDC) estimated 687,000 HAIs in US acute care hospitals, causing 72,000 deaths and estimated costs of $\$ 97-147$ billion annually $[19,20]$. Furthermore, in low and middle incomes countries, such as Brazil, the frequency of infection acquired in the ICU is at least 2-3 and up to 5 times higher than in high-income countries [21,22] and 5-10 times greater than those acquired in general clinical wards and surgery [23].

In Brazil, a study found an incidence of adverse events of $8.4 \%$ in hospitalized patients, with HAI being the second most frequent (20\% of cases) after surgical events (24.6\%) [24]. A multi-stage survey, carried out in Brazil with a team of trained data collectors, detected an overall prevalence rate of HAI of 10.8\% [25]. Another study carried out in Brazil demonstrated the general prevalence of HAIs, which was higher $(51.2 \%)$ than that reported for the USA $(6.1 \%)$ and Europe $(48.4 \%)$ in multicenter surveillance studies [26-28], but similar to other Brazilian studies [29-31]. In this study, the highest prevalence $(78.6 \%)$ was observed in a unit located in the northern region of the state, the region with the lowest income [32].

Antimicrobial resistance is one of the most complex health challenges today. Despite warnings from international organizations, the world has long ignored warnings that antibiotics and other drugs are losing their effectiveness after decades of overuse and improper use in human medicine, animal health, and agriculture [33,34]. Common diseases such as pneumonia, postoperative infections, diarrhea, among others, are becoming increasingly intractable due to the emergence and spread of drug resistance. Unfortunately, antibiotic consumption increases in some countries, especially in low and middle-income countries [35]. In the past few years, some high-income countries have decreased the consumption of antibiotics, suggesting that the educational/regulatory strategies developed in recent years significantly reduced consumption [36]. However, if no policy change is made, the projection of global antibiotic consumption in 2030 will be up to $200 \%$ [35].

The antimicrobial resistance is one of the three most critical problems for human health $[37,38]$, and the most common and severe multidrug-resistant pathogens (MDR) that cause HAIs are Clostridium difficile and the bacteria included in the acronym "ESKAPE" (Enterococcus spp., Staphylococcus aureus, Klebsiella spp., Acinetobacter spp., Pseudomonas aeruginosa, and Enterobacteriaceae) [39]. In addition, many bacteria exhibit antimicrobial resistance and can cause bloodstream infections, urinary tract, severe pneumonia, and surgical site infection [9]. Thus, the only possible defense against the threat of antimicrobial resistance and the possibility of a post-antibiotic era is all stakeholders' global and coordinated effort to support the development of new antimicrobial drugs, diagnostics, vaccines, and other tools.

The hospital environment is seen as an essential reservoir of microorganisms, especially multidrug-resistant ones. Among the factors that favor the contamination of the health service environment, we can mention the hands of health professionals in contact with the surfaces, maintenance of damp, wet and dusty surfaces, imperfect coatings, and organic matter maintenance [40,41]. The presence of dirt, especially organic matter of human origin, can serve as a substrate for the proliferation of microorganisms or favor the company of vectors, which can passively carry these agents. Hence the importance of cleaning and rapid disinfection of any area with organic matter, regardless of the hospital area [42-45]. Although effective disinfection of surfaces and the environment is considered one of the primary measures to control the spread of HAIs, hospital surfaces remain neglected reservoirs.

Some traditional disinfecting hospital environments' apparent lack of effectiveness $[46,47]$ stimulated the search for new decontamination methods that are also "environmentally friendly." As a result, there has been engagement in using ozone gas as 
a chemical element for antimicrobial control in several areas [48-53] and as a disinfectant [54-57].

Ozone (O3) is a bioactive oxidizing disinfectant that decomposes into $\mathrm{O}_{2}$ and $\mathrm{O}_{1}$, and the latter molecule is highly reactive, causing the breakdown of bacterial cell walls and changing the function of proteins and carbohydrates [56,57]. Gaseous and water-based $\mathrm{O}_{3}$, used for disinfection in the food industry and water systems, is currently being studied to interrupt biofilms in periodontics [54-57]. $\mathrm{O}_{3}$ has a half-life of approximately $20 \mathrm{~min}$ in the gaseous phase, which has restricted some applications before low concentration exposures for prolonged periods, with limited effectiveness [58]. However, $\mathrm{O}_{3}$ has already been applied to clean hospital clothing [59], and a recent study demonstrated the eradication of methicillin-resistant Staphylococcus aureus (MRSA) in a nurse's home environment after $\mathrm{O}_{3}$ decontamination [49]. Gaseous ozone in relatively high concentrations ( 25 parts per million - ppm) has also been used to inactivate norovirus and bacteria in office and hotel rooms, removing this ozone after using a system purifier [50,51]. In medicine, $\mathrm{O}_{3}$ has already been used in different forms of application (parenteral or local), aiming to combat ischemia, joint diseases, immunosuppression, degenerative diseases, and infections [60-62] and for therapeutic purposes [63,64]. However, in high concentrations, it becomes toxic [65]. Thus, different beneficial effects can be obtained if used correctly and in a controlled manner.

Thus, considering the emergence of microorganisms resistant to conventional antimicrobials and that the use of $\mathrm{O}_{3}$ is considered an effective disinfectant of low cost. In this work, we have determined the minimal concentration of $\mathrm{O}_{3}$ necessary to control and kill a set of Gram-positive and Gram-negative bacteria. Also analyzed were cell viability, membrane permeability, intracellular reactive oxygen species (ROS) levels, and ultrastructural bacterial membrane damage.

\section{Materials and Methods}

\subsection{Bacterial strains}

Standard strains (Staphylococcus aureus (ATCC 6538), Salmonella enterica subsp enterica serovar choleraesuis (ATCC 10708), Escherichia coli (ATCC 25922), and Pseudomonas aeruginosa (ATCC 15442) were obtained from the American Type Culture Collection (ATCC) (Plast Labor Ind Com EH Lab Ltda, RJ, Brazil). The MDR strain of Acinetobacter baumannii with origin from the local hospital, carrying the blaOXA-23 gene and representing one of the genotypes disseminated in Brazil (ST15 / CC15), was also used. This strain was kindly provided by Dr. Maria H. S. Villas-Bôas (National Institute for Quality Control in Health of the Oswaldo Cruz Foundation-INCQS/FIOCRUZ). These bacterial strains were initially cultivated according to the instructions of the ATCC, aliquoted, and stored in cryotubes containing Tryptic Soy Broth (TSB, Difco) with 20\% glycerol (v/v) and kept at $-20^{\circ} \mathrm{C}$ for later use.

\subsection{Ozone generating and monitoring}

An air purifier/sterilizer with O3 (SANITECH O3 PURI-MU, Astech Serv. and Fabrication Ltda., Petropolis, RJ, Brazil) with the capacity to treat the room air up to $30 \mathrm{~m}^{3}$ was used. The monitoring and measurement of the environmental concentration of $\mathrm{O} 3$ emitted were realized using a portable gas detector (BH-90A, Forensics LLC, Los Angeles, CA, USA). This detector monitored combustible and toxic gases using a biolt-in MCU sensor controller with a range of 0 to $20 \mathrm{ppm}$ with two alarms set at $5 \mathrm{ppm}$ and $10 \mathrm{ppm}$.

\subsection{Inoculation of the test surface}

The strains were removed from the freezer stock culture for bacterial reactivation, sown in TSB, and incubated at $37^{\circ} \mathrm{C}$ for $24 \mathrm{~h}$. After the microorganisms were suspended in sterile $0.85 \%$ saline and the concentration of $108 \mathrm{CFU} \mathrm{m}{ }^{-1}$ was determined with a densitometer (Densichek Plus, BioMérieux, USA). The successive dilutions $\left(10^{4}, 10^{3}\right.$, and $10^{2} \mathrm{CFU} \mathrm{ml}{ }^{-1}$ ) were made in the Brain Heart Infusion broth (BHI). One hundred microliter 
aliquots of each bacterial suspension (S. aureus, S. enterica, E. coli, P. aeruginosa, and A. baumannii in different concentrations $\left(10^{4}, 10^{3}\right.$, and $\left.10^{2} \mathrm{CFU} \mathrm{ml}-1\right)$ were plated in triplicate by spread plate on Triptona Soy Agar (TSA; Difco) and incubated at $37^{\circ} \mathrm{C}$ for $24 \mathrm{~h}$.

\subsection{Ozone treatment}

The inoculated plates containing the different microorganisms were placed on a laboratory bench measuring $2.55 \mathrm{~m} 2(2.50 \mathrm{~m} \times 0.62 \mathrm{~m})$ equidistant and symmetrically opposed, then opened and exposed to only one SANITECH O3 PURI-MU device (turned on $1 \mathrm{~h}$ before starting the experiment and approximately 1.10 meters away) for $10 \mathrm{~h}$ and $12 \mathrm{~h}$ exposure to ozone in a test room measuring about $38 \mathrm{~m} 3(3.60 \mathrm{mx} 3.65 \mathrm{~m} \times 2.90 \mathrm{~m})$, kept closed, except when measuring and monitoring the environmental $\mathrm{O} 3$ concentration. After the exposure time, the plates were closed and incubated at $37^{\circ} \mathrm{C}$ for $24 \mathrm{~h}$.

As a positive control of the assay, plates with TSA containing the same bacterial suspensions were used without exposure to $\mathrm{O}_{3}$. These control plates remained at room temperature and were incubated at $37^{\circ} \mathrm{C}$ for $24 \mathrm{~h}$ together with the plates exposed to $\mathrm{O}_{3}$. A plate containing only TSA was used as a negative control. The test was performed in triplicate. Colony counting was performed only on plates with many colonies from 0 to 300.

\subsection{Cell Viability}

The cell viability was measured on selected bacterial suspension of $10^{3} \mathrm{CFU} \mathrm{ml} \mathrm{m}^{-1}$ after $10 \mathrm{~h}$ exposure to $\mathrm{O}_{3}$ based on previous results (cell count- CFU ml-1). The entire previous experiment was performed again (at the defined concentration and time), and after $24 \mathrm{~h}$ of incubation, three distinct colonies from each plate were inoculated separately in a test tube containing BHI broth (Difco). As a positive control of the assay, we performed the same procedure with the plates that were not exposed to $\mathrm{O}_{3}$, where three distinct colonies of each dish were inoculated separately in a test tube containing BHI broth (Difco). Afterward, $100 \mu \mathrm{L}$ of the bacterial suspension of each colony was transferred, in triplicate, to the wells of the 96-well microplate, which was incubated at $37^{\circ} \mathrm{C}$ for $24 \mathrm{~h}$. Each strain was tested in duplicate and detected bacterial growth by adding $0.02 \%$ resazurin (7hydroxy-phenoxazin-3-one 10-oxide; Sigma-Merck, St Louis, MO, USA) and $1 \mathrm{~h}$ incubation [66]. Resazurin is a non-toxic, non-fluorescent blue reagent that, after enzymatic reduction, becomes highly fluorescent. This conversion occurs only in viable cells, and as such, the amount of resorufin produced is proportional to the number of viable cells in the sample [67-69]. As a negative control, we used BHI broth, and the measured at $590 \mathrm{~nm}$ was made on an ELISA plate reader (Flex Station 3, Molecular Devices, San José, CA, USA).

The collected data were analyzed using the program $R$ (version 3.6.0) and R Studio, where the paired t-test was applied to compare the statistical significance between the two samples (with and without treatment with $\mathrm{O}_{3}$ ) with $\leq 0.01$. Each experiment was repeated three times for each microorganism in each treatment with $\mathrm{O}_{3}$.

\subsection{Live/Dead assay}

The effect of ozone on bacteria membrane permeability was measured using fluorescent probes to stain live (Syto9) and dead bacteria with the disrupted membrane (propidium iodide; PI). Briefly, bacteria suspension $\left(10^{3} \mathrm{CFU} \mathrm{ml} \mathrm{m}^{-1}\right)$ was cultivated in BHI broth for $24 \mathrm{~h}$ in 24 well plates in the presence of $\mathrm{O}_{3}$. After exposure, cultures were incubated with $15 \mu \mathrm{M}$ of PI (Sigma-Aldrich, St Louis, MO, USA) and $2 \mu \mathrm{M}$ of Syto9 (Thermo, Waltham, MA, USA) for 15 minutes in the dark. Cells were washed three times by centrifugation ( $4000 \times \mathrm{g}$ for $5 \mathrm{~min}$ ) in PBS. Then cell suspension was smeared onto a glass slide and analyzed on an Axio Imager M2 microscope (Carl Zeiss do Brazil Ltda, São Paulo, SP, Brazil). Captured fluorescence of live/dead cells and differential interference contrast (DIC) images for each field of view from multiple areas for analysis. 
Quantification was performed using the Knime workflow of different bacteria colonies [70].

\subsection{Measurement of reactive oxygen species (ROS) levels}

Intracellular ROS levels were measured in $\mathrm{O}_{3}$ treated and not treated bacteria $(A$. baumannii MDR, E. coli (ATCC 25922), and $P$. aeruginosa (ATCC 15442). Bacteria suspension in BHI $\left(10^{3} \mathrm{CFU} \mathrm{ml}{ }^{-1}\right)$ was cultivated in plates of 24 wells for $10 \mathrm{~h}$ in the presence of $\mathrm{O}_{3}$. As positive controls, the bacteria were incubated for 30 min in $\mathrm{H}_{2} \mathrm{O}_{2}(1 \%$

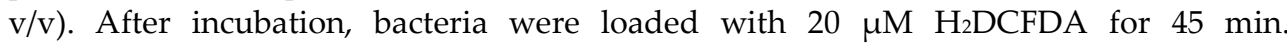
Fluorescence signal, generated by the probe's oxidation by intracellular ROS, was measured using 485/535 nm excitation/emission wavelengths with a Spectra Max -M2 microplate reader (Molecular Devices, CA, USA) [71].

Each experiment was repeated three times for each microorganism in each treatment with O3. The paired t-test was applied to compare the statistical significance between the two parts (With and without treatment with $\mathrm{O}_{3}$ ). Differences were determined significant if $\mathrm{p} \leq 0.05$.

\subsection{Scanning electron microscopy (SEM)}

Morphological changes in the bacteria species were visualized using SEM. For analysis, control cells or under $\mathrm{O}_{3}$ treatment were fixed for $1 \mathrm{~h}$ with $2.5 \%$ glutaraldehyde in $0.1 \mathrm{M}$ cacodylate buffer. After fixation, the cells were washed three times in PBS for 5 min, post-fixed for $15 \mathrm{~min}$ in $1 \%$ osmium tetroxide (OsO4) and washed again three times in PBS for $5 \mathrm{~min}$. Next, the samples were dehydrated in an ascending series of ethanol $\left(7.5,15,30,50,70,90\right.$ and $100 \%$ ethanol) for 15 min each step, critical point dried with $\mathrm{CO}_{2}$, sputter-coated with a 15-nm thick layer of gold and examined in a Jeol JSM 6390 (Tokyo, Japan) scanning electron microscope.

\section{Results}

\subsection{Monitoring of ozone concentration}

The monitoring of the $\mathrm{O}_{3}$ concentration in the test room $\left(27^{\circ} \mathrm{C}\right)$ showed that the device's emission ranged from $0.6 \mathrm{ppm}$ to $2.1 \mathrm{ppm}$, with the average of all measurements around $1.4 \mathrm{ppm}$.

\subsection{Ozone treatment}

The culture exposure at different times $\left(10 \mathrm{~h}\right.$ and $12 \mathrm{~h}$ ) with Low-level of gaseous $\mathrm{O}_{3}$ did not wholly prevent the growth in vitro of all tested bacterial strains (Figure 1). No reduction in colony count compared to the control group (not treated with $\mathrm{O}_{3}$ ) was observed as statistically significant. For strains A. baumannii MDR and S. aureus ATCC 6538 , the count of bacterial colonies in the control group was higher than those that underwent treatment with $\mathrm{O}_{3}$, but with no statistically significant difference. In the other strains of S. enterica ATCC 10708, P. aeruginosa ATCC 15442, and E. coli ATCC 25922, Os did not affect bacterial proliferation compared to the baseline group. 


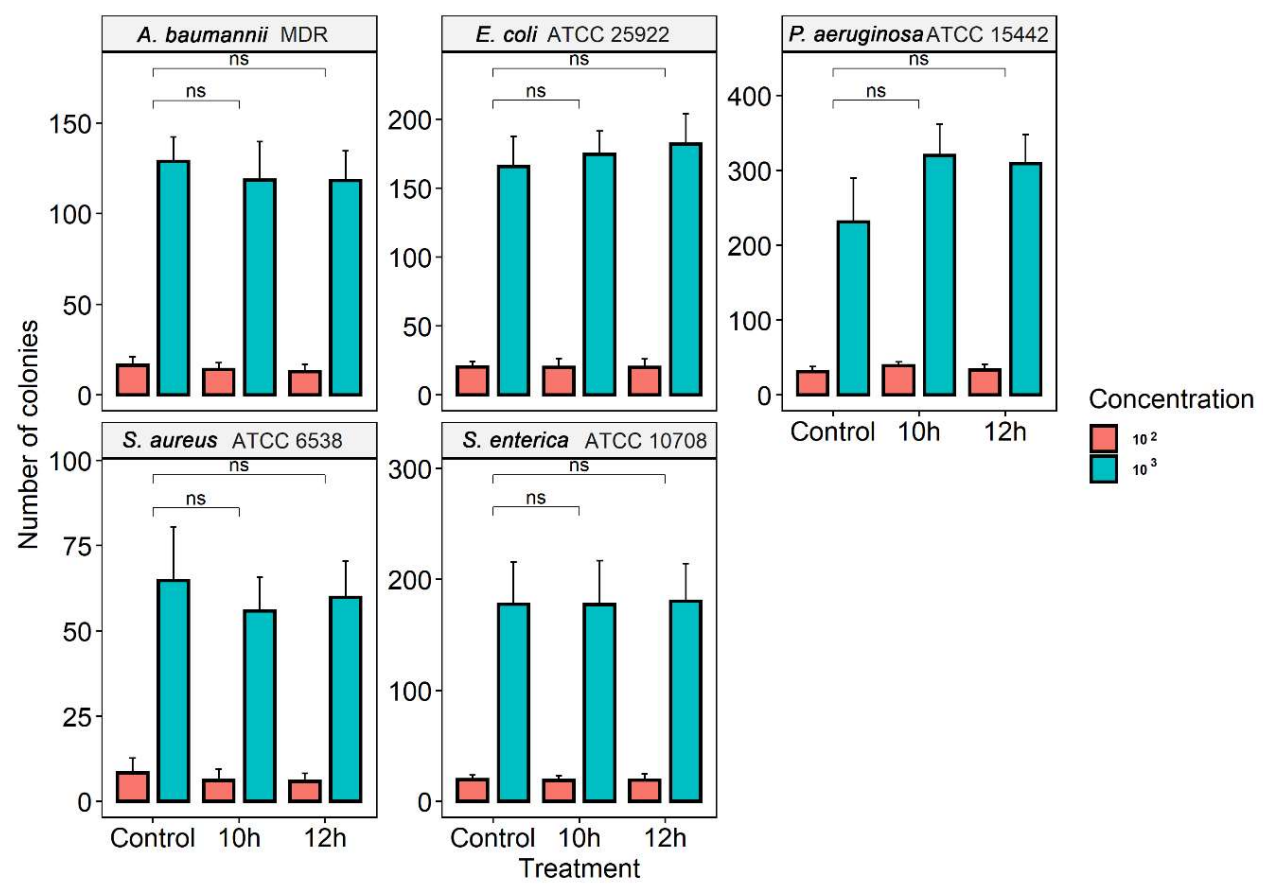

Figure 1. Counting the number of colonies in different species of bacteria (A. baumannii MDR, S. aureus (ATCC 6538), S. enterica (ATCC 10708), E. coli (ATCC 25922) and P. aeruginosa (ATCC 15442). Quantification of the number of colonies was performed in the control group (without treatment) and in bacterial suspensions $\left(10^{3}\right.$ and $\left.10^{2} \mathrm{CFU} / \mathrm{mL}\right)$ after exposure to $\mathrm{O}_{3}$ for $10 \mathrm{~h}$ and 12 h. ns: statistically not significant using the t-test.

However, as the colony count does not provide information regarding the metabolic, functional, and proliferative capacity of the bacteria, the cell viability assay in solution was investigated using resazurin as a metabolic indicator. In this assay, after $\mathrm{O}_{3}$ treatment, three random colonies were incubated in TSB medium, and after $24 \mathrm{~h}$, the viability of the different species was measured (Figure 2). A significant difference was observed in the viability of A. baumannii, E. coli, and P. aeruginosa treated with $\mathrm{O}_{3}$. Ozone treatment mainly reduced the bacterial growth of $E$. coli, leading to an inhibition of about $30 \%$, followed by P. aeruginosa (25\%) and A. baumannii (15\%). After the O3-treatment of S. aureus and S. enterica found no differences in the viability. 


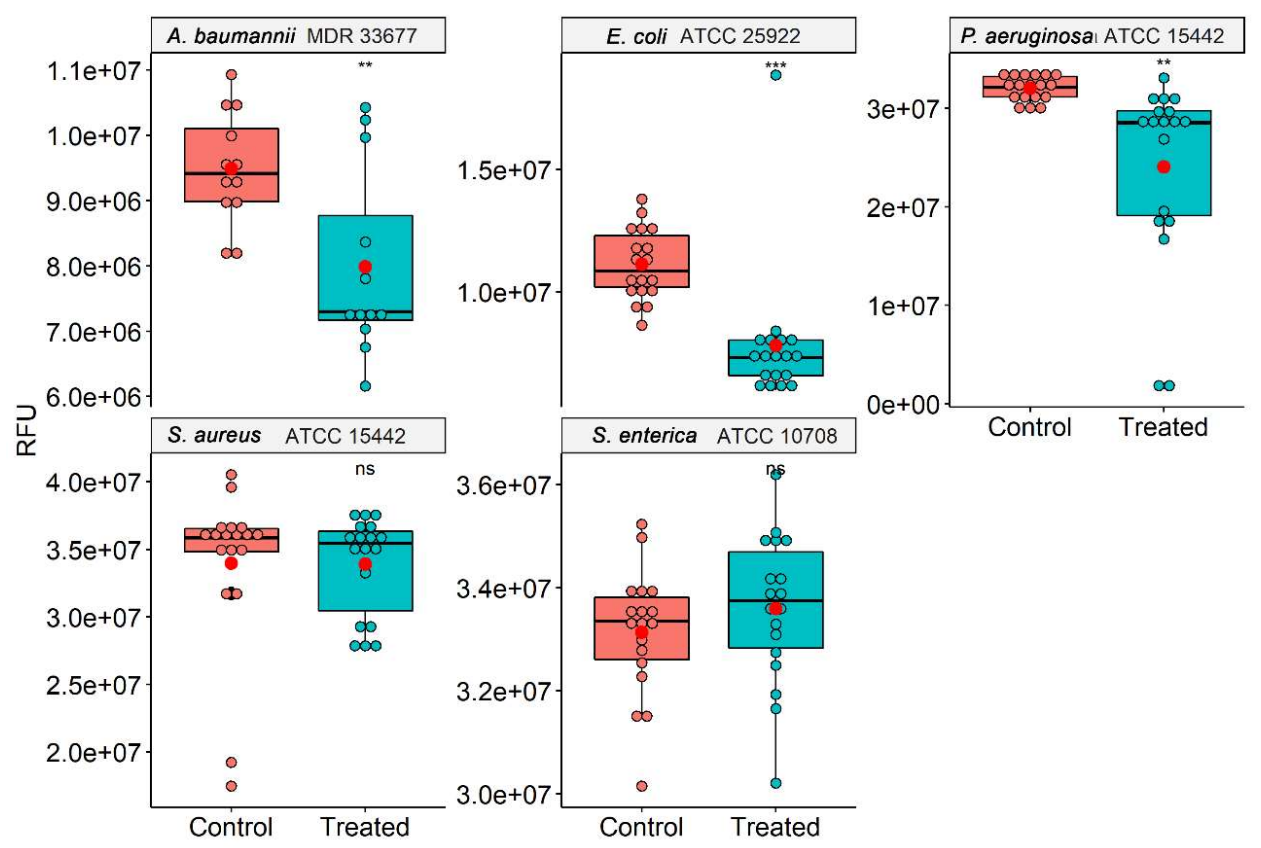

Figure 2. Viability of different bacteria (A. baumannii, E. coli, P. aeruginosa, S. aureus and S. enterica) after exposure to ozone for $10 \mathrm{~h}$ using resazurin as a metabolic indicator. Viable bacteria convert resazurin into fluorescent resofurin, comparison of $\mathrm{O}_{3}$ exposure of different colonies was visualized in boxplot. Red dots represent the mean of the relative fluorescence from each group. Statistic significant using t-test $\left(* * \mathrm{p}<0.01 ;{ }^{* * *} \mathrm{p}<0.001\right)$.

\subsection{Effect of ozone}

The use of PI as a membrane permeability indicator showed that the bacterial membranes of all strains from ATCC were not affected by ozone. No difference statistic was observed when compared to untreated control (Figure 3). Representative fluorescence images comparing untreated, and Ozone treated groups also showed no difference in the distribution of PI permeable bacteria (Figure 4).

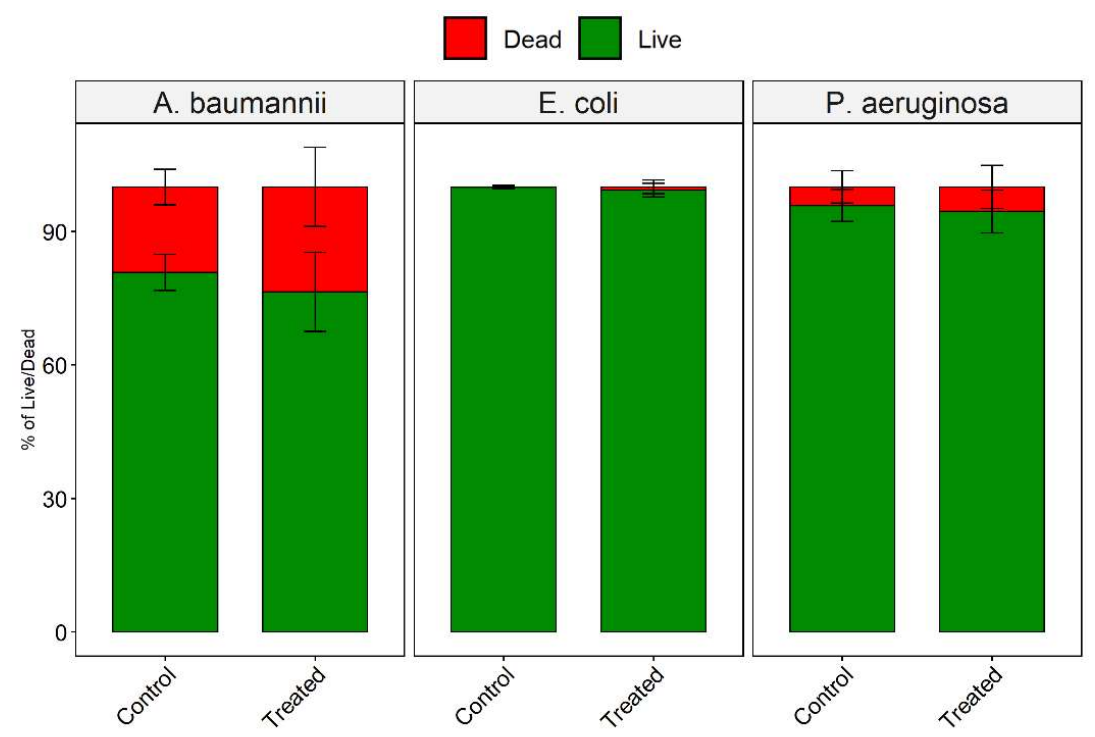

Figure 3. Quantification of Live/Dead bacteria, after exposure to $\mathrm{O}_{3}$ for $10 \mathrm{~h}$. Percentage of live and dead cells quantified from different microscopic images. 


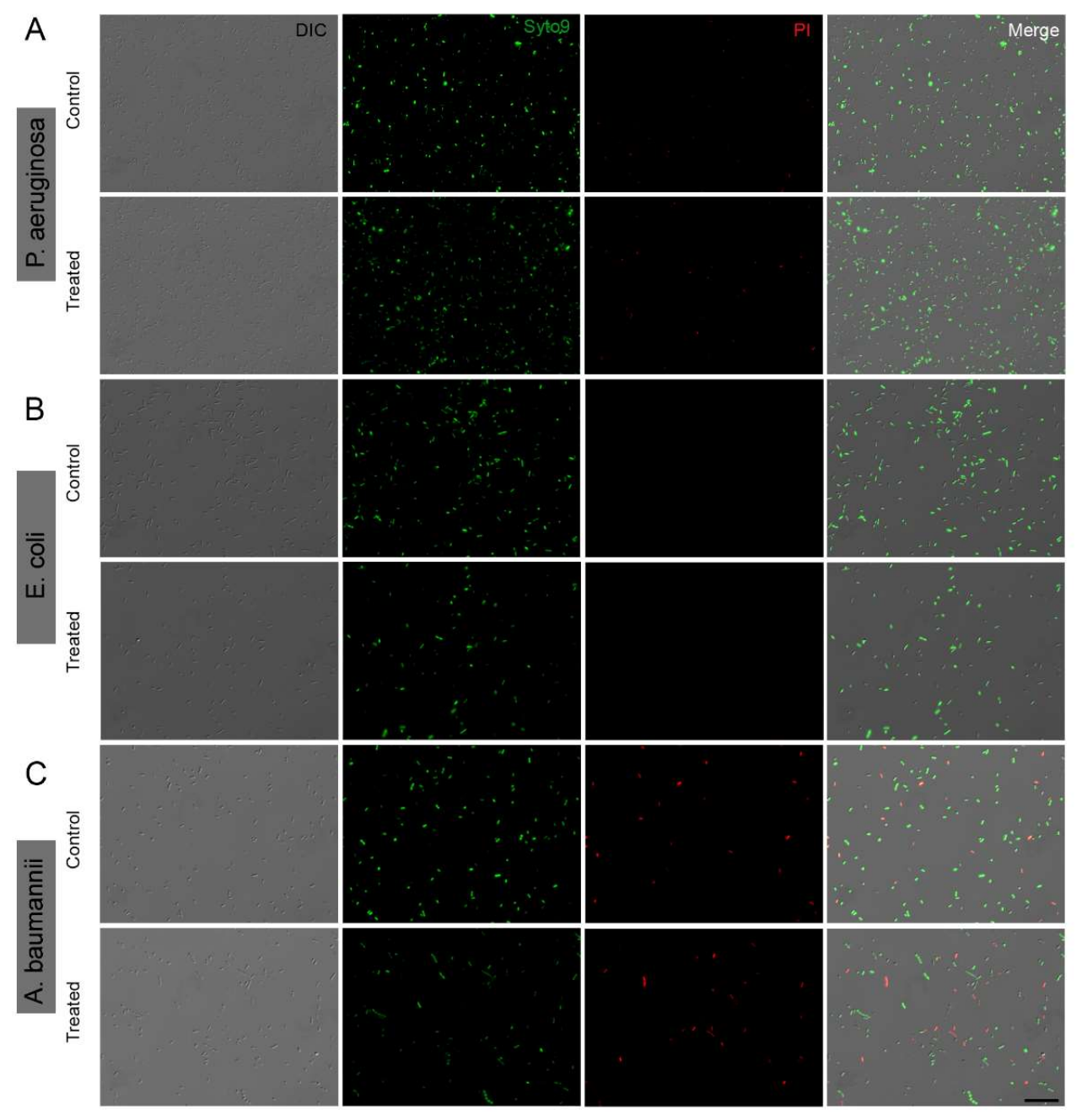

Figure 4. Fluorescence images of P. aeruginosa (A), E. coli (B) and A. baumannii (C) exposed to $\mathrm{O}_{3}$ for $10 \mathrm{~h}$ and stained with Syto9 (green) and Propidium iodide (PI; red). Live bacteria were evidenced using Syto9, while membrane permeable dead bacteria were stained with PI. DIC: Differential interference contrast. Bar $=20 \mu \mathrm{m}$.

\subsection{ROS analysis}

Since $\mathrm{O}_{3}$ diffuses in solution and decomposes to elemental oxygen and free radicals, we measured the oxidative stress produced by ozone treatment using a fluorescent probe. Results demonstrate a significant increase of ROS in the ozone-treated group for the three pathogenic bacteria. Compared to untreated control, the increase in ROS was higher in $E$.

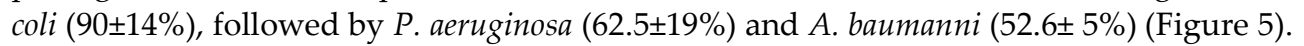
E. coli is more sensible to oxidizing agents since $\mathrm{H}_{2} \mathrm{O}_{2}$ leads to an increase of approximately $215 \%$ compared to basal ROS production of the control group. A. baumannii and $P$. aeruginosa had a similar increase upon $\mathrm{H} 2 \mathrm{O} 2$ treatment, 171 and $173 \%$, respectively (Figure 5). 


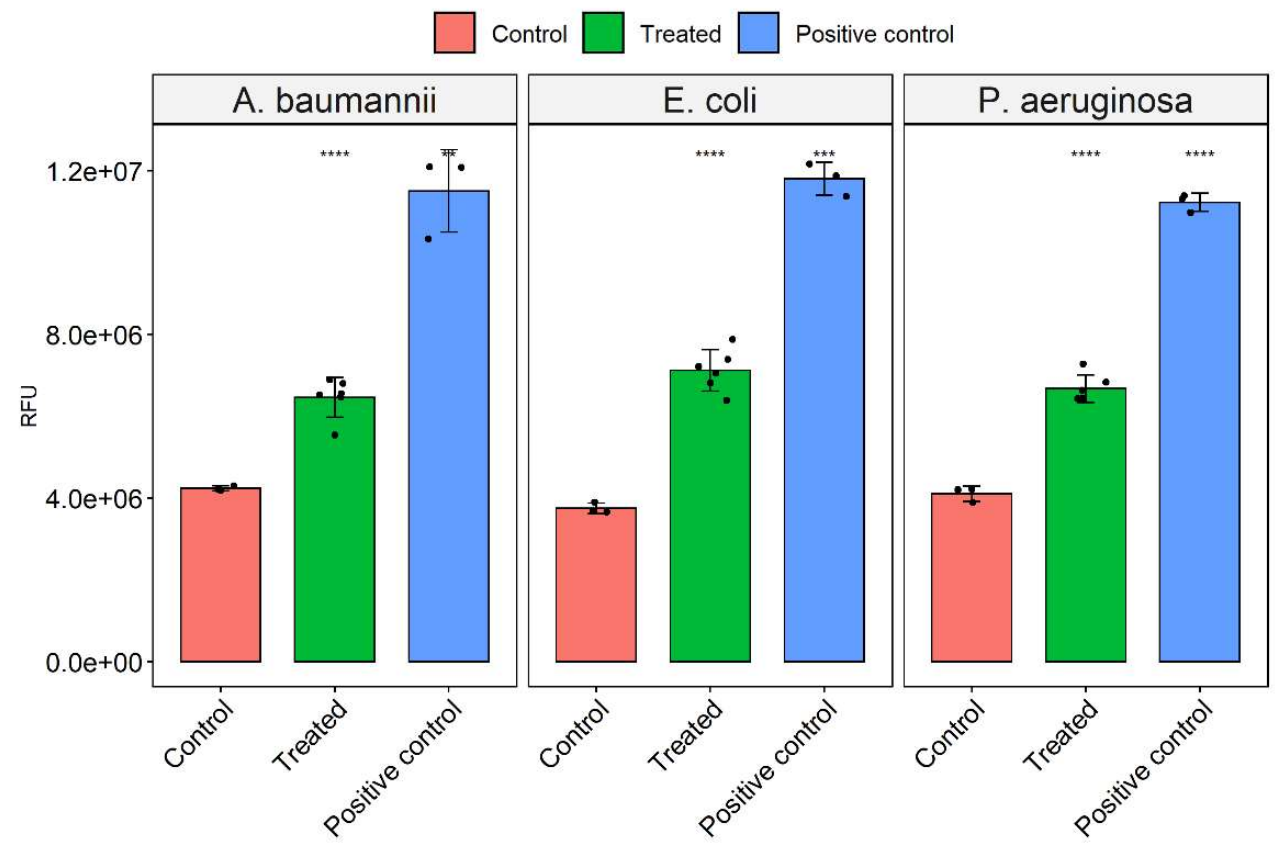

Figure 5. Measurement of reactive oxygen species (ROS) induced by $\mathrm{O}_{3}$ on different bacteria after incubation during $10 \mathrm{~h}$. Hydrogen peroxide (1\%) was used as positive control. The data represent the mean and standard deviation of triplicates using different colonies. t-test $\left(^{* * *}\right) \mathrm{p}<0.01$ and $\left({ }^{* * * *}\right)$ $\mathrm{p}<0.001$.

\subsection{Scanning electron microscopy (SEM)}

Scanning electron microscopy was performed to confirm membrane damage to bacterial species. Morphological analysis showed a striking effect of $\mathrm{O}_{3}$ in $A$. baumannii. Treated bacteria showed many protrusions that resemble membrane blebbing. All bacterial controls showed smooth and homogeneous surfaces. Both E.coli and P. aeruginosa present membrane alterations after $\mathrm{O} 3$ treatment. The treatment produced in bacterial membrane wrinkle cells with damaged areas with invagination (Figure 6). 

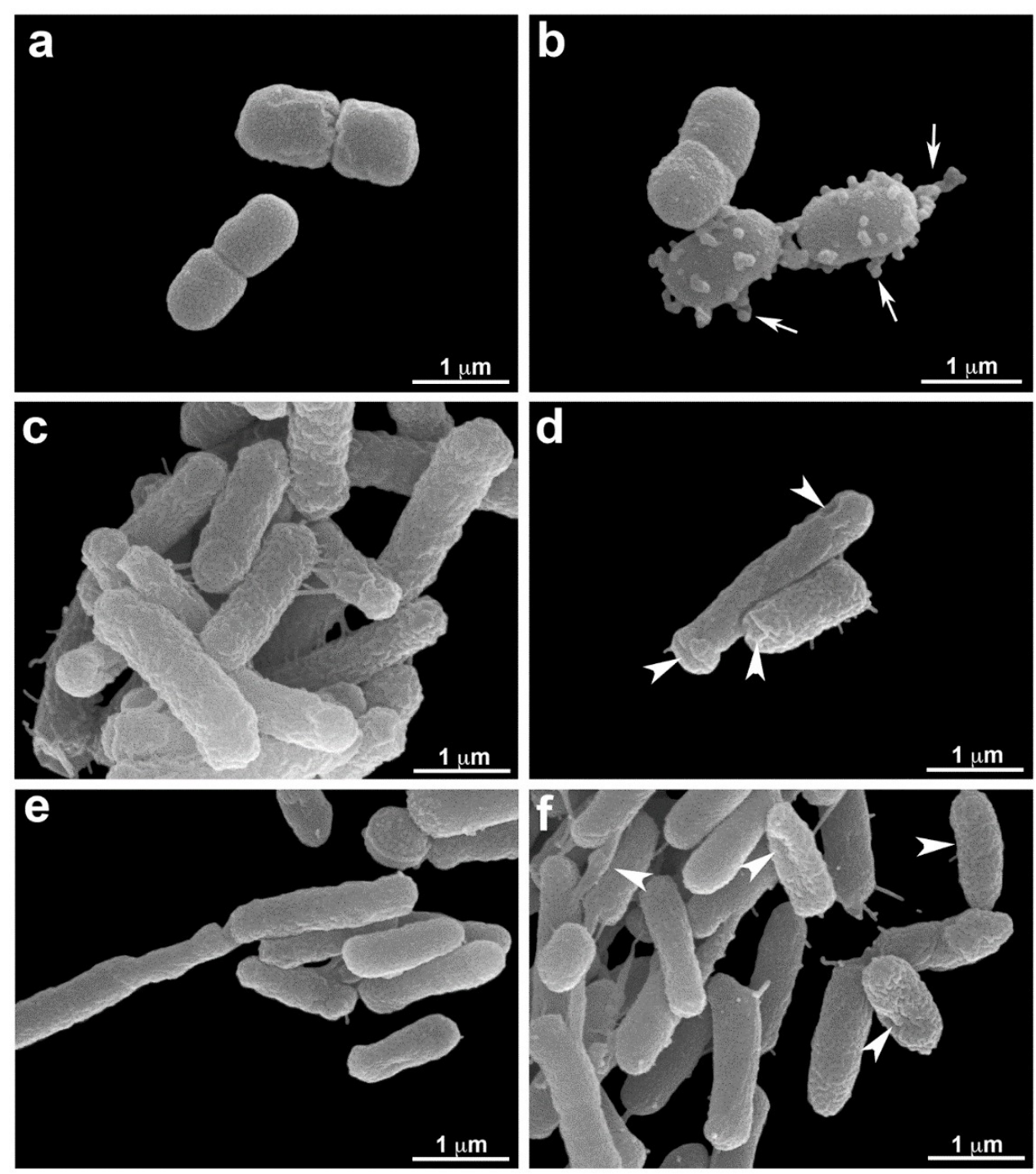

Figure 6. Morphological analysis of $\mathrm{O}_{3}$ treatment by electron microscopy. A. baumannii (a-b), E. coli (c-d), and P. aeruginosa (e-f) are seen without (a, c, e) and under $\mathrm{O}_{3}$ treatment (b, d, f). Membrane protrusions (arrows) are seen in A. baumannii after treatment (b). Note that control cells exhibit a homogeneous surface (a). Both $E$. coli and $P$. aeruginosa present surface alterations after treatment $(\mathrm{d}, \mathrm{f})$. Observing more wrinkle cells is possible than control ones (c,e), and some damage is verified (arrowhead).

\section{Discussion}

Antimicrobial resistance is a growing and worrying concern inside and outside the hospital environment. Although several studies have shown that the bactericidal effect of $\mathrm{O}_{3}$ is better with higher concentrations of exposure than lower ones [72,73], little is known about its bactericidal effect when used in low concentrations since the results are limited or inconclusive. Therefore, in this study, we have evaluated the antimicrobial efficiency of a low concentration of $\mathrm{O}_{3}$ in five bacteria, measuring the cell viability and cytotoxic effect. Four of these bacteria strains are recommended by the Association of Official Analytical Chemists [74] and the National Institute of Quality Control of Brazil (INCQS; POP No. 65.3210.007 [75] and one multidrug-resistant (MDR) A. baumannii, a bacterium commonly present in patients with severe nosocomial infections.

The concentration of $\mathrm{O}_{3}$ produced by an Ozonator depends on the size of the area, equipment capacity, if there are open doors, or if there are materials that react with $\mathrm{O}_{3}$ on the site [76,77]. 
Major regulatory bodies have issued rules and laws that regulate the maximum number of hours allowed for particular gas concentrations in the workplace. The United States Department of Labor's Occupational Safety and Health Administration (OSHA) allows maximum exposure of $0.1 \mathrm{ppm}$ of $\mathrm{O}_{3}$ in 8-hour work environments [78]. The Environmental Protection Agency (EPA), through the Code of Federal Regulations (CRF) -Tile 21, allows maximum exposure of 0.05 ppm of gas [79]. In Brazil, safe dosages of O3 in work environments are indicated by the Ministry of Labor, through the Regulatory Norm ((NR) 15, annex 11) [80], which means a maximum exposure of $0.08 \mathrm{ppm}(0.16 \mathrm{mg}$ $/ \mathrm{m}^{3}$ ) for working hours of up to 48 hours per week. There are factors in the work environment that must be considered, such as ventilation and other elements that act in the destruction of the $\mathrm{O}_{3}$ molecule.

Measurements were made to estimate the $\mathrm{O}_{3}$ concentration in ambient air generated by the air purifier/sterilizer with $\mathrm{O}_{3}$, directly on the output grid of the SANITECH PURI$\mathrm{MU}$ device with the emission ranging from 0.6 to $2.1 \mathrm{ppm}$. The Eco Sensors Division of KWJ Engineering Inc, which is the leading designer of gas detection and $\mathrm{O}_{3}$ detection instruments for industrial environments and personal protection, meeting the safety needs of workers in detecting $\mathrm{O}_{3}$ and gas since 1992 [81], determines that the $\mathrm{O}_{3}$ concentration decreases rapidly as the measuring distance from the generator increases. For example, ozone that reads ten ppm directly in the output grid rarely exceeds $0.1 \mathrm{ppm}$ at 1 meter from the generator [82]. Therefore, according to our results, we can presume that at a 1-meter distance, the $\mathrm{O}_{3}$ level is approximately 0.006 to $0.021 \mathrm{ppm}$ which is lower than $0.1 \mathrm{ppm}$, the legally permissible exposure limit set by the Occupational Safety and Health Administration (OSHA) of safe levels of $\mathrm{O}_{3}$ emission in busy environments ensuring its non-toxicity.

The effectiveness of $\mathrm{O}_{3}$ for disinfecting surfaces and rooms has been examined in several previous studies, and many of them have used low $\mathrm{O}_{3}$ concentrations because of the toxic nature of the gas and its relatively long half-life [58,83-86]. Nevertheless, the use of low $\mathrm{O} 3$ concentrations generally leads to limited or inconclusive results. Despite not obtaining a significant reduction of in vitro bacteria growth, when we investigated its metabolic capacity through resazurin, we found a significant decrease in values for three of the five bacteria studied, showing that even at low concentrations, $\mathrm{O}_{3}$ was able to interfere with cell viability. In addition, we found that $\mathrm{O}_{3}$ presented the highest inhibitory effect on E. coli (30\%), followed by P. aeruginosa (25\%) and A. baumannii (15\%). Among bacteria, $E$. coli is known to be the most sensitive to $\mathrm{O}_{3}$.

Low doses of $\mathrm{O}_{3}$ can effectively control cryptosporidium and Mycobacterium avium [87]. A study showed that a single topical application by nebulizing a low amount of $\mathrm{O}_{3}$ could completely inhibit the growth of several potentially pathogenic bacterial strains with known resistance to antimicrobial agents [88]. On the contrary, gram-positive cocci (Staphylococcus and Streptococcus) and viruses are more resistant to $\mathrm{O}_{3}$. Although, ozone can sterilize both gram-positive bacteria and gram-negative bacteria [89]. Ozone is an unstable molecule that rapidly decays to $\mathrm{O}_{2}$ and releases a single oxygen atom. The single oxygen atom reacts with the cell membrane of the bacteria, attacks the cellular components, interrupts the regular cell activity, and then destroys bacteria [89-91]. Another study verified the effectiveness of ozone as a terminal disinfectant by evaluating different microorganisms inoculated in stainless steel squares and incubated at various temperatures and relative humidity for up to $4 \mathrm{~h}$. Contaminated yards were set identically compared after exposure to $\mathrm{O}_{3}(2 \mathrm{ppm} / 4 \mathrm{~h})$ the survival of these microorganisms. The disclosure of $\mathrm{O}_{3}$ to the dirty surfaces resulted in a reduction in microbial viability that varied depending on the type of organism (7.56 to $2.41 \log$ values), suggesting that, if applied after adequate cleaning, ozone can be used as an effective terminal disinfectant [92]. An in vitro study observed that $\mathrm{O}_{3}$ effectively reduces concentrations of A. baumannii, Clostridium difficile, and methicillin-resistant S. aureus (MRSA) in dry and wet samples, suggesting that it can be used as a disinfectant [51].

Oxidative stress is defined as a disturbance of the prooxidant/antioxidant balance in favor of prooxidants, leading to potential damage to the cell [93]. Excess pro oxidants 
result in oxidative stress, damaging cell components such as proteins, lipids, and DNA oxidation [94,95]. Oxidative stress induces free radicals with highly reactive elements such as reactive oxygen species (ROS), which can attack biological molecules and lead to death [96]. The O3 is a strong oxidant that generates reactive oxygen species (ROS) in tissue and causes DNA damage [97]. In our analysis, the permeability of the bacterial membrane of all strains from ATCC was not significantly affected by ozone, with no difference in the distribution of PI-positive bacteria. However, we observed a significant increase of ROS in the ozone-treated group for $E$. coli $(90 \pm 14 \%)$, followed by $P$. aeruginosa $(62.5 \pm 19 \%)$

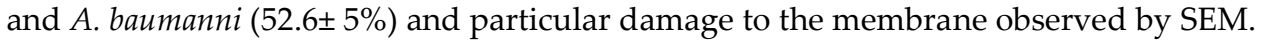

It is well known that ozone is poisonous; this is an essential factor in air pollution, particularly affecting children, inhalation can damage the lungs with possible serious consequences [98]. However, in common with many other therapies that induce ROS, the outcome of treatment with ozone, at shallow doses, can be beneficial rather than damaging [99-101].

Although the microbicide effect of $\mathrm{O}_{3}$ is known, its mechanism of action is nameless. A previous study evaluated the bactericidal effect under low $\mathrm{O}_{3}$ concentration and found that the negative and positive ions generated during exposure induced oxidative stress, including oxidation of amino acids, cell wall reaction [102], and DNA damage [103], causing cell death. It has been hypnotized that the cell lysis depends on the extent of the reaction [102]. The primary cellular targets for $\mathrm{O}_{3}$ are nucleic acids, where damage can range from base lesions to single and double-strand breaks [104]. Lesions can lead to more or less compromising point mutations, whereas massive DNA breakage is lethal if not repaired [105-107]. Many other studies provide evidence that the cell envelope is affected during ozonation, probably even before severe DNA damage occurs [108-110].

The effectiveness of $\mathrm{O}_{3}$ as a disinfectant varies significantly between different types of bacteria, even at the strain level as shown previously $[104,111]$ and by our analysis. However, its effect depends on several intrinsic factors, such as growth stage, cell envelope, the efficiency of repair mechanisms, and the type of viability indicator used [112-114]. Besides that, some other extrinsic factors, such as concentration and type of dissolved organic material or the presence of flakes or particles, may reduce $\mathrm{O}_{3}$ stability or may protect microorganisms from its effects, thereby decreasing the disinfection efficiency [115-118]. Nevertheless, ozone gas has been successfully applied to disinfection viruses on surfaces and aerosols $[119,120]$.

\section{Conclusions}

This work shows that low doses of ozone did not inhibit bacterial growth but may interfere with the cell viability of the three bacterial strains studied. There was no damage to bacterial membranes, but measurement of oxidative stress showed a significant increase in intracellular levels of reactive oxygen species (ROS) that damage lipids, proteins, and DNA. Furthermore, significant morphological changes such as protrusions resembling membrane blisters and/or invaginations were observed in E. coli and $P$. aeruginosa after treatment with $\mathrm{O}_{3}$.

These results are promising and encourage further investigations into using gaseous ozone at low concentrations as a disinfectant or antiseptic, evaluating its bactericidal effect, as it can reduce the transmission of microorganisms and is essential in the maintenance and/or disinfection of health environments.

Author Contributions: Conceptualization, K.R.; formal analysis, K.R., G.C.L., V.M, F.O.C and J.P.R.S.C; data curation, M.H.S.V.B.; writing - review and editing, K.R, S.G.D-S.; visualization, K.R., and S.G.D-S.; supervision, K.R.; funding acquisition, S.G.D-S. All authors have read and agreed to the published version of the manuscript.

Funding: This research was funded by the Carlos Chagas Filho Foundation for Research Support of the State of Rio de Janeiro (FAPERJ nº E-26 110.198-13; E26 202.841-2018) and the Brazilian Council for Scientific Research (CNPq-nº 467.488.2014-2; 3075732011; 3013322015-0). 
Data Availability Statement: The data presented in this study are available on request from the corresponding author.

Acknowledgments: The Electron microscopy platform Rudolf Barth from Oswaldo Cruz Institute/FIOCRUZ for electron microscopy analysis facilities. K.R. and G.C.L. are Post-doc fellows from CAPES/CDTS and CNPq, respectively. J.P.R.S. is a CAPES/MSci fellow from the Science and Biotechnology Post Graduation program of the Federal Fluminense University.

Conflicts of Interest: The authors declare no conflict of interest.

\section{References}

1. Coelho, F.; Coelho, M.; Diniz, A.; Vicente, G.; Vieira, C. Velhos Problemas novos desafios. Rev Tecn Hospitalar. 2011 , 43, 30-32.

2. Ratti, R.P.; Sousa, C.P. Staphylococcus aureus meticilina resistente MRSA e infecções nosocomiais. Vet. Ciên. Farm. Básica e Apl. 2009; 30: 137- 143.

3. Haque, M.; Sartelli, M.; McKimm, J.; Bakar, M.A. Health care-associated infections - an overview. Infect. Drug Resist. 2018; 11: 2321-2333.

4. WHO (2011) Word Health Organization. Report on the Burden of Endemic Health Care-Associated Infection Worldwide. Available at: https://apps.who.int/iris/ handle/10665/80135 (Acessed 14 May 2021).

5. Lax, S.; Gilbert, J.A. Hospital-associated microbiota and implications for nosocomial infections. Trends Mol. Med. 2015; 21: 427432.

6. Calfee, D.P. Crisis in hospital-acquired healthcare-associated infections. Annu Rev Med. 2011; 63: 359-371.

7. Teerawattanapong, N.; Panich, P.; Kulpokin, D.; Ranong, S.N.; Kongpakwattana Atibodi Saksinanon, K.; Goh, B.; Lee, L.; Apisarnthanarak, A.; Chaiyakunapruk, N. A systematic review of the burden of multidrugresistant healthcare-associated infections among intensive care unit patients in Southeast Asia: the rise of multidrug-resistant Acinetobacter baumannii. Infect. Control Hosp. Epidemiol. 2018; 39: 525-533.

8. Walter, J.; Haller, S.; Quinten, C.; Kärki, T.; Zacher, B.; Eckmanns, T.; Sin, M.A.; Plachouras, D.; Kinross, P.; Suetens, C.; Ecdc Pps Study Group. Healthcare-associated pneumonia in acute care hospitals in European union/European economic area countries: an analysis of data from a point prevalence survey 2011 to 2012. Eurosurveillance 2018; 23: 1-12.

9. Agaba, P.; Tumukunde, J.; Tindimwewa, J.V.B.; Kwizera, A. Nosocomial bacterial infections and their antimicrobial susceptibility patterns among patients in Ugandan intensive care units: a cross sectional study. BMC Res. Notes. 2017; 10: 349.

10. Curcio, D.; Alí, A.; Duarte, A.; Pauta, A. D.; Ibáñez-Gúzman, C.; Sang M. C.; Valencia E.; Plano F.; Paredes Oña, F.; Arancibia, F.; Montufar Andrade, F.; Morales Alava, F.; Cañarte Bermudez, G.; La Fuente Zerain, G.; Alanis Mirones, V.; Rojas Suarez, J.; Guzmán Torrico, J.; Silva, J.; Vergara Centeno, J.; Medina, J.C.; Marín, K.; Caero, L.A.; Durán Crespo, L.; Gómez Duque, M.; Játiva, M.; Belloni, R.; Romero, R.; Aguilera Perrogón, R.; Camacho Alarcón, R.; Camargo, R.; Cevallos, S.; Intriago Cedeño, V.; Urbina Contreras, Z..Latin American antibiotic use in intensive care unit group. Prescription of antibiotics in intensive care units in Latin America: an observational study. J. Chemother. 2009; 21: 527-534.

11. Curcio, D.J. On behalf of the Latin American antibiotic use in intensive care unit group. Antibiotic prescription in intensive care units in Latin America. Rev. Argent. Microbiol. 2011; 43: 203-211.

12. Monnet, D.L.; Archibald, L.K.; Phillips, L.; Tenover, F.C.; McGowan Jr; J.E.; Gaynes, R.P. Antimicrobial use and resistance in eight US hospitals: complexities of analysis and modeling. Intensive care antimicrobial resistance epidemiology project and national NISSH. Nosocomial infections surveillance system hospitals. Infect. Control Hosp. Epidemiol. 1998; 19: 388-394.

13. Fujimura, S.; Nakano, Y.; Sato, T.; Shirahata, K.; Watanabe, A. Relationship between the usage of carbapenem antibiotics and the incidence of imipenem-resistant Pseudomonas aeruginosa. J. Infect. Chemother. 2007; 13: 147-150.

14. Rogues, A.M.; Dumartin, C.; Amadéo, B.; Venier, A.G.; Marty, N.; Parneix, P.; Gachie, J.P. Relationship between rates of antimicrobial consumption and the incidence of antimicrobial resistance in Staphylococcus aureus and Pseudomonas aeruginosa isolates from 47 French hospitals. Infect. Control Hosp. Epidemiol. 2007; 28: 1389-1395.

15. Iosifidis, E.; Antachopoulos, C.; Tsivitanidou, M.; Katragkou, A.; Farmaki, E.; Tsiakou, M.; Kyriazi, T.; Sofianou, D.; Roilides, E. Differential correlation between rates of antimicrobial drug consumption and prevalence of antimicrobial resistance in a tertiary care hospital in Greece. Infect. Control Hosp. Epidemiol. 2008; 29: 615-622.

16. Sales, V. M.; Oliveira, E.; Célia, R.; Gonçalves, F.R.; Melo, C.C. Análise microbiológica de superfícies inanimadas de uma Unidade de Terapia Intensiva e a segurança do paciente. Rev Enfer Ref. 2014; 4: 45-53.

17. Nogueira Jr, C.; Padoveze, M.C.; and Lacerda, R.A.; Governmental surveillance sys-tem of healthcare-associated infection in Brazil. Rev. Esc. Enferm. USP. 2014; 48: 657-662.

18. Souza, E.S.; Belei, R.A.; Carrilho, C.M.D.M.; Matsuo, T.; Ogatta, S.F.Y.; Andrade, G.; Perugini, M.R.E.; Pieri, F.M.; Dessunti, E. M.; Kerbauy, G. Mortalidade e riscos associados a infecção relacionada à assistência à saúde. Texto Contexto Enferm. 2015; 24: 220-228.

19. Magill, S.S.; Edwards, J.R.; Bamberg, W.; Beldavs, Z.G.; Dumyati, G.; Kainer, M.A.; Lynfield, R.; Maloney, M.; McAllisterHollod, L.; Nadle, J.; et al. Multistate point-prevalence survey of health care-associated infections. N. Engl. J. Med. 2014; 370: 1198-1208.

20. CDC (2015) Centers for disease control and prevention. Healthcare-associated infections-Hospital Prevalence Survey. Available at: https://www.cdc.gov/hai/ index.html. (Acessed 18 April 2021). 
21. WHO (2016) World Health Organization. Health care-associated infections fact sheet. Available at: http://www.who.int/gpsc/ country_work/gpsc_ccisc_fact_sheet_en.pdf. (Acessed 18 May 2021).

22. Rosenthal, V.D.; Al-Abdely, H.M.; El-Kholy, A.A.; AlKhawaja, S.A.A.; Leblebicioglu Yatin Mehta, H.; Rai, V.; Hung, N. V.; Kanj, S. S.; Salama, M. F.; Salgado-Yepez, International nosocomial infection control consortium report data summary of 50 countries for 2010-2015: device-associated module. Am. J. Infect. Control. 2016; 44: 1495-1504.

23. Weber, D.J.; Raasch, R.; Rutala, W.A. Nosocomial infections in the ICU: the growing importance of antibiotic-resistant pathogens. Chest. 1999; 115: 34S-41S.

24. Mendes, W.; Pavão, A.L.B.; Martins, M.; Moura, M. L.O.; Travassos, C.; Características de eventos adversos evitáveis em hospitais do Rio de Janeiro. Rev. Assoc. Med. Bras. 2013; 59: 42188.

25. Fortaleza, C.M.C.B.; Padoveze, M.C.; Kiffer, C.R.V.; Barth, A.L.; Carneiro, I.C.R.S.; Giamberardino, H.I.G.; Rodrigues, J.L.N.; Filho, L.S.; Gonçalves de Mello, M J.; Severino Pereira, M.; et al. Multi-state survey of healthcare-associated infections in acute care hospitals in Brazil. J. Hosp .Infect. 2017; 96: 139-144.

26. Richards, M.J.; Edwards, J.R.; Culver, D.H.; Gaynes, R.P. Nosocomial infections in combined medical-surgical intensive care units in the United States. Infect. Control Hosp. Epidemiol. 2000; 21: 510-515.

27. Vincent, J.L.; Rello, J.; Marshall, J.; Silva, E.; Anzueto, A.; Martin, C.D.; Moreno, R.; Lipman, J.; Gomersall, C.; Sakr, Y.; Reinhart, K.; EPIC II group of investigators. International study of the prevalence and outcomes of infection in intensive care units. JAMA. 2009; 302: 2323-2329.

28. Blot, S.; Antonelli, M.; Arvaniti, K.; Blot, K.; Creagh-Brown, B.; de Lange, D.; De Waele, J.; Deschepper, M.; Dikmen, Y.; Dimopoulos, G.; Eckmann, C.; Francois, G.; Girardis, M.; Koulenti, D.; Labeau, S.; Lipman, J.; Lipovestky, F.; Maseda, E.; Montravers, P.; Mikstacki, A.; Paiva, J.A.; Pereyra, C.; Rello, J.; Timsit, J.F.; Vogelaers, D.; Abdominal Sepsis Study (AbSeS) group on behalf of the Trials Group of the European Society of Intensive Care Medicine. Epidemiology of intra-abdominal infection and sepsis in critically ill patients: "AbSeS", a multinational observational cohort study and ESICM Trials Group Project. Int. Care Med. 2019; 45: 1703-1717.

29. Garner, J.S. The hospital infection control practices advisory committee. Guideline for isolation precautions in hospital. Infect. Control Hosp. Epidemiol. 1996; 17: 54-80.

30. Lisboa, T.; Faria, M.; Hoher, J.A.; Borges, L.A.A.; Gómez, J.; Schifelbain, L.; Dias, F.S.; Lisboa, J.; Friedman, G. Prevalência de infecção nosocomial em unidades de terapia intensiva do Rio Grande do Sul. Rev. Bras. Ter. Int. 2007; 19: 414-420.

31. Silva, E.; Junior, L.D.; Fernandes, H.S.; Moreno, R.; Jean-Louis Vincent, J.; Prevalence and outcomes of infections in Brazilian ICUs: a sub analysis of EPIC II study. Rev. Bras. Ter. Intensiva 2012; 24: 143-150.

32. Braga, I.A.; Campos, P.A.; Gontijo-Filho, P.P.; Ribas, R.M. Multi-hospital point prevalence study of healthcare-associated infections in 28 adult intensive care units in Brazil. J. Hosp. Infect. 2018; 99: 318-324.

33. UN (2019) UNITED NATIONS. Health Agency Steps Up Fight against 'invisible pandemic' of antimicrobial resistance. Available at: https://news.un.org/en/story/2019/06/1040741. (Acessed 21 May 2021).

34. WHO (2020) World Health Organization - Antibiotic Resistance. Newsroom 2020. Available at: https: //www.who.int/newsroom/fact-sheets/detail/antibioticresis tance. (Acessed 21 May 2021).

35. Klein, E.Y.; Van Boeckel, T.P.; Martinez, E.M.; Pant, S.; Gandra, S.; Levin, S.A.; Goossens, H.; Laxminarayan, R. Global increase and geographic convergence in antibiotic consumption between 2000 and 2015. Proc Natl Acad Sci USA. 2018, 115, E3463-E3470.

36. O'neill, J. Tackling drug-resistant infections globally: Final report and recommendations. Rev. Antimicrob. Resist. 2016.

37. Bassetti, M.; Ginocchio, F.; Mikulska M. New treatment options against gram negative organisms. Crit. Care 2011, 15, 215.

38. WHO (2017) World Health Organization. Global priority list of antibiotic-resistant bacteria to guide research discovery and development of new antibiotics 2017. Available at: https://www. who.int/medicines/publications/global-priority-list-antibioticresistant-bacteria/en/ (Acessed 21 May 2021).

39. Magill, S.S.; O’Leary, E.; Janelle, S.J.; Thompson, D.L.; Dumyati, G.; Nadle, J.; Wilson, L.E.; Kainer, M.A.; Lynfield, R.; Greissman, S.; Ray, S.M.; Beldavs, Z.; Gross, C.; Bamberg, W.; Sievers, M.; Concannon, C.; Buhr, N.; Warnke, L.; Maloney, M.; Ocampo, V.; Brooks, J.; Oyewumi, T.; Sharmin, S.; Richards, K.; Rainbow, J.; Samper, M.; Hancock, E.B.; Leaptrot, D.; Scalise, E.; Badrun, F.; Phelps, R.; Edwards, J.R.; emerging infections program hospital prevalence survey team. Changes in prevalence of health care-associated infections in U.S. Hospitals. N. Engl. J Med. 2018; 379: 1732-1744.

40. Garner, J.S. The hospital infection control practices advisory committee. Guideline for isolation precautions in hospital. Infect Control Hosp Epidemiol. 1996; 17: 54-80.

41. Oliveira, A.C. 2005 Infecções hospitalares epidemiologia prevenção e controle. Rio de Janeiro: Medsi.

42. Pelczar, M.J.; Chan, E.C.S.; Krieg, N.R. 1997 Microbiologia conceitos e aplicações. São Paulo: Makron Books.

43. Fernandes, A.T.; Fernandes, M.O.V.; Ribeiro Filho, N.; Graziano, K.U. Gabrielloni, M.C. Cavalcante, N.J.F.; Lacerda, R.A. Infecção hospitalar e suas interfaces na área da saúde. São Paulo: Atheneu 2000.

44. Rutala, W.; Gergen, M.F.; Tande, B.M.; Weber, D.J. Rapid hospital room decontamination using ultravioleta UV light with a nanostructured UV-reflective wall coating. Infect. Control Hosp. Epidemiol. 2013; 34: 527-529.

45. Han, J.H.; Sullivan, N.; Leas, B.F.; Pegues, D.A.; Kaczmarek, J.L.; Umscheid, C.A. Cleaning hospital room surfaces to prevent health care-associated infections. Ann Int Med. 2015; 163:598-607.

46. Blythe, D.; Keenlyside, D.; Dawson, S.J.; Galloway, A. Environmental contamination due to methicillin-resistant Staphylococcus aureus (MRSA). J. Hosp. Infect. 1998;, 38: 67-69. 
47. French, G.L.; Otter, J.A.; Shannon, K.P.; Adams, N.M.T.; Watling, D.; Parks, M.J. Tackling contamination of the hospital environment by methicillin resistant Staphylococcus aureus MRSA: a comparison between conventional terminal cleaning and hydrogen peroxide vapour decontamination. J. Hosp. Infect. 2004; 57: 31-37.

48. Fan, L.; Song, J.; Hildebrand, P.D.; Forney, C.F. Interaction of ozone and negative air ions to control micro-organisms. J. Appl. Microbiol. 2002; 93: 144-148.

49. De Boer, H.E.L.; Van Elzelingen-Dekker, C.M.; Van Rheenen-Vernerg, C.M.; Spanjaard, L. Use of gaseous ozone for eradication of methicillin resistant Staphylococcus aureus from the home environment of a colonized hospital employee. Infect. Control Hosp Epidemiol. 2006; 27: 1120-1122.

50. Hudson, J.B.; Sharma, M.; Petric, M. Inactivation of Norovirus by ozone gas in conditions relevant to healthcare. J. Hosp. Infect. 2007; 66: 40-45.

51. Sharma, M.; Hudson, J.B.; Ozone gas is an effective and practical antibacterial agent. Am. J. Infect. Control. 2008; $36: 559-563$.

52. Elvis, A.M.; Ekta, J.S. Ozone therapy: A clinical review. J. Nat. Sc. Biol .Med. 2011; 2: 66-70.

53. Wallace, C.A. New developments in disinfection and sterilization. Am. J. Infect. Control 2016; 44: e23-7.

54. Huth, K.C.; Quirling, M.; Maier, S.; Kamereck, K.; Alkhayer, M.; Paschos, E.; Welsch, U.; Miethke T.; Brand, K.; Hickel, R. Effectiveness of ozone against endodontopathogenic microorganisms in a root canal biofilm model. Int. Endod. J. 2009; 42: 3-13.

55. Rosenblum, J.; Ge C.; Bohrerova, Z.; Yousef, A.; Lee, J. Ozonation as a clean technology for fresh produce industry and environment: sanitizer efficiency and wastewater quality. J. Appl. Microbiol. 2012; 113: 837-845.

56. Martinelli, M.; Giovannangeli, F.; Rotunno, S.; Trombetta, C.M.; Montomoli, E.; Water and air ozone treatment as an alternative sanitizing technology. J. Prev. Med Hyg. 2017; 58: E48-E52.

57. Bitter, K.; Vlassakids, A.; Niepel, M.; Hoedke, D.; Schulze, J.; Neumann, K.; Moter, A.; Noetzel J. Effects of diode laser gaseous ozone and medical dressings on Enterococcus faecalis biofilms in the root canal ex vivo. Biomed. Res. Int. 2017; $2017: 6321850$.

58. Berrington, A.W.; Pedler S.J. Investigation of gaseous ozone for MRSA decontamination of hospital side-rooms. J. Hosp. Infect. 1998; 40: 61-65.

59. Cardoso, C.C.; Fiorini, J.E.; Gurjão, J.W.B.; Amaral, L.A. Disinfection of hospital laundry using ozone: microbiological evaluation. Infect. Control Hosp. Epidemiol. 2000; 21: 248.

60. Bocci V. Is ozone therapy therapeutic? Perspect. Biol. Med. 1998; 42: 131-143.

61. Bocci V. Biological and clinical effects of ozone: Has ozone therapy a future in medicine? Br. J. Biomed Sci. 1999; 56: 270-279.

62. Di Paolo, N.; Bocci, V.; Gaggiotti, E. Ozone therapy editorial review. Int. J. Artif. Organs 2004; 27: 168-175.

63. Carvalho, C.F.; Brioschi, M.L.; Teixeira, M.J. Uso da termografia na avaliação da ozonioterapia como tratamento da epicondilite lateral. Pan. Am. J. Med. Thermology 2015; 2: 90-93.

64. Manoto, S.L.; Maepa, M.J.; Motaung, S.K.; Medical ozone therapy as a potential treatment modality for regeneration of damaged articular cartilage in osteoarthritis. Saudi. J. Biol. Sci. 2016; 25: 672-679.

65. Silva, R.A.; Garotti, J.E.R.; Silva, R.S.B.; Navarini, A.; Pacheco-Jr, A.M. Analysis of the bactericidal effect of ozone pneumo peritoneum. Acta Cir. Bras. 2009; 24: 124-127.

66. Lall, N.; Henley-Smith, C.J.; Canha, M.N.; Oosthuizen, C.B.; Barrington, D. Viability reagent prestoblue in comparison with other available reagents utilized in cytotoxicity and antimicrobial assays. Int. J. Microbiol. 2013; 2013: 420601.

67. Riss, T.; Moravec, R.; Niles, A. Development for cell viability and apoptosis for high-throughput screening. In: Chen T. A practical guide to assay development and high-throughput screening in drug discovery. CRC Press. 2010;109-110.

68. Riss, T.; Moravec, R.A.; Niles, A.L.; Duellman, S.; Benink, H.A.; Worzella, T.J.; Minor, L.; Markossian, S.; Grossman, A.; Brimacombe, et al. Cell Viability Assays. In: SITTAMPALAM G. The assay Guidance Manual. Eli Lilly Co., National Center for Advancing Translational Sciences, Bethesda, USA. 2016, p. 10-12.

69. Präbst, K.; Engelhardt, H.; Ringgeler, S.; Hübner, H. Basic colorimetric proliferation assays: MTT WST and Resazurin. Methods Mol Biol. 2017; 1601: 1-17.

70. Rangel, K.; Lechuga, G.C.; Souza, A.L.A.; Carvalho, J.P.R.S.; Villas-Bôas, M.H.S.; De-Simone, S.G. Pan-drug resistant Acinetobacter baumannii but not other strains are resistant to the bee venom peptide mellitin. Antibiotics (Basel) 2020; 9: 178.

71. Lara, L.S.; Moreira, C.S.; Calvet, C.M.; Lechuga, G.C.; Souza, R.S.; Bourguignon, S.C.; Ferreira, V.F.; Rocha, D.; Pereira, M.C.S. Efficacy of 2-hydroxy-3-phenylsulfanylmethyl-[14]-naphthoquinone derivatives against different Trypanosoma cruzi discrete type units: Identification of a promising hit compound. Eur. J. Med. Chem. 2018; 144: 572-581.

72. Nogales, C.G.; Ferreira, M.B.; Lage-Marques, J.L.; Comparison of the antimicrobial activity of three different concentrations of aqueous ozone on Pseudomonas aeruginosa, Staphylococcus aureus and Enterococcus faecalis- in vitro study. Rev. Esp. Ozonoterapia 2014; 4: 9-15.

73. Tormin, S.C.; Navarrini, A.; Almeida, J.O.C.F.; Travassos, L.H.R.; Negri, M.V.G.; Silva,R.A. Análise do efeito bactericida do ozônio sobre bactérias multirresistentes. Arq. Med. Hosp. Fac. Ciências Médicas da Santa Casa de São Paulo. 2016; 61: 138-141.

74. Tomasino, S. Disinfectants. In: Official Methods of Analysis. 19 $9^{\text {th }}$ ed. Association of Official Analytical Chemists chap. 6. 2012.

75. Manual da qualidade. Método da diluição de uso. 2013 Rev. 10. In: Manual da Qualidade. Rio de Janeiro: INCQS/FIOCRUZ. Seção 10. 21 p. 65.3210 .007 rev. 10.

76. Mcclurkin, J.D.; Maier, D.E.; Ileleji, K.E. Half-life time of ozone as a function of air movement and conditions in a sealed container. J. Stored Prod. Res. 2013; 55: 41-47.

77. Nemmich, S.; Tilmatine, A.; Dey, Z.; Hammadi, N.; Nassour, K.; Messal, S. Optimal sizing of a DBD ozone generator using response surface modeling ozone: science and engineering. J. Int. Ozone Assoc. 2015; 37: 3-8. 
78. Osha; 1992 Ocuppational safety and health administration; U.S. Department of health and human services. Available at: http://www.osha.gov/dts/chemicalsampling/data/CH_259 300.html (Acessed 14 May 2021).

79. EPA (2015) Environmental Protection Agency. Available at: http://www.epa.gov/indoor-air-quality-iaq/ozone-generators-aresold-air-cleaners\#generators-effective (Acessed 21 May 2021).

80. BRASIL (2016) Ministério do Trabalho e Emprego. Norma Regulamentadora (NR) 15 NR 15 Anexo 11: Atividades e Operações Insalubres. Available at: http://www.mte.gov.br/legislacao/ normas_regulamentadoras/nr_15_anexo11.pdf (Acessed 14 May 2021).

81. ECO Sensors Company (2020). Available at: https://www.ecosensors.com /company/ (Acessed 21 May 2021).

82. ECO Sensors Company (2020). Available at: http://www.ecosensors.com /wpcontent/uploads/ old/MO-100.pdf. (Acessed May 2021).

83. Masaoka, T.; Kubota, Y.; Namiuchi, S.; Takubo, T.; Ueda, T.; Shibata, H.; Nakamura, H.; Yoshitake, J.; Yamayoshi, T.; , Doi, H.; Kamiki T. Ozone decontamination of bioclean rooms. Appl. Environ. Microbiol. 2002; 43: 509-513.

84. Dyas, A.; Boughton, B. J.; Das, B. C. Ozone killing action against bacterial and fungal species; microbiological testing of a domestic ozone generator. J. Clin. Pathol. 1983; 36: 1102-1104.

85. Ishizaki, K.; Sawadaishi, K.; Miura, K.; Shinriki, N. Effect of ozone on plasmid DNA of Escherichia coli in situ. Water Res. 1987; 21: 823-827.

86. Whistler, P.E.; Sheldon, B.W.; Comparison of ozone and formaldehyde as poultry hatchery disinfectants. Poult Sci. 1989; 68: $1345-1350$.

87. WHO (2004) World Health Organization. Water treatment and pathogen control. Available at: https://www.who.int/water sanitation_health/water-quality/guidelines/en/watreatpath3. pdf (Acessed 14 May 2021).

88. Fontes, B.; Heimbecker, A.M.C.; Brito, G.S.; Costa, S.F.; Van Der Heijden, I.M.; Levin, A.S.; Rasslan, R. Effect of low-dose gaseous ozone on pathogenic bacteria. BMC Infect. Dis. 2012; 12: 358.

89. Almaz, M.E.; Sönmez, I.Ş. Ozone therapy in the management and prevention of caries. J. Formos Med. Assoc. 2015; $114:$ 3-11.

90. Yamayoshi, T.; Tatsumi, N. Microbicidal effects of ozone solution on methicillin-resistant Staphylococcus aureus. Drugs Exp. Clin. Res. 1993; 19: 59-64.

91. Komanapalli, I.R.; Lau, B.H. Inactivation of bacteriophage lambda Escherichia coli and Candida albicans by ozone. Appl. Microbiol. Biotechnol. 1998; 49: 766-769.

92. Moore, G.; Griffith, C.; Peters, A.; Bactericidal properties of ozone and its potential application as a terminal disinfectant. J. Food Prot. 2000; 63: 1100-1106.

93. Sies, H. Oxidative stress: a concept in redox biology and medicine. Redox Biol. 2015; 4: 180-183.

94. Farr, S.B.; Kogoma, T. Oxidative stress responses in Escherichia coli and Salmonella typhimurium. Microbiol Rev. 1991; 55: 561-585.

95. Yoshikawa, T.; Naito, Y. What is oxidative stress? Jpn. Med. Assoc. J. 2002; 45: 271-276.

96. Vatansever, F.; De Melo, W.C.M.A.; Avci, P.; Vecchio, D.; Sadasivam, M.; Gupta, A.; Chandran, R.; Karimi, M.; Parizotto, N. A.; Yin,. R; et al. Antimicrobial strategies centered around reactive oxygen species - bactericidal antibiotics photodynamic therapy and beyond. FEMS Microbiol. Ver. 2013; 37: 955-989.

97. Cheng, T.J.; Kao, H.P.; Chan, C.C.; Chang, W.P. Effects of ozone on DNA single-strand breaks and 8-oxoguanine formation in A549 cells. Environ. Res. 2003; 93: 279-284.

98. Mathineu-Nolf, M. Poisons in the air: a cause of chronic disease in children. J. Toxicol. Clin. Toxicol. 2002; 40: 483-91.

99. Bocci V. Ozone as Janus: this controversial gas can be either toxic or medically useful. Mediators Inflamm. 2004; 13: 3-11.

100. Bocci, V.; Borrelli, E.; Travagli, V.; Zanardi I. The ozone paradox: ozone is a strong oxidant as well as a medical drug. Med. Res. Rev. 2009; 29: 646-682.

101. Valacchi, G.; Fortino, V.; Bocci, V. The dual action of ozone on the skin. Br. J. Dermatol. 2005; 153: 1096-1100.

102. Velano, H.E.; Nascimento, L.C.; De Barros, L.M.; Panzeri, H. Avaliação in vitro da atividade antibacteriana da água ozonizada frente ao Staphylococcus aureus. Pesq. Odontol. Bras. 2001; 151: 18-22.

103. Park, J.S.; Sung, B.J.; Yoon, K.S.; Jeong, C.S. The bactericidal effect of an ionizer under low concentration of ozone. BMC Microbiol. 2016; 16: 173.

104. Von Sonntag, C.; Von Gunten, U. Chemistry of ozone in water and wastewater treatment from basic principles to applications; IWA Publishing: London. 2012.

105. Hamelin, C.; Chung, Y. S. Optimal conditions for mutagenesis by ozone in Escherichia coli K12. Mutat. Res. 1974; $24: 271-279$.

106. Hamelin, C.; Sarhan, F.; Chung, Y.S. Ozone induced DNA degradation in different DNA polymerase I mutants of Escherichia coli K12. Biochem. Biophys Res. Commun. 1977; 77: 220-224.

107. Hamelin, C.; Sarhan, F.; Chung, Y.S. Induction of deoxyribonucleic acid degradation in Escherichia coli by ozone. Experientia 1978; 34: 1578-1579.

108. Scott, D. B. M.; Lesher, E. C. Effect of ozone on survival and permeability of Escherichia coli. J. Bacteriol. 1963; 85: 567-576.

109. Hunt, N.K.; Mariñas, B.J. Inactivation of Escherichia coli with ozone: chemical and inactivation kinetics. Water Res. 1999; 33: 2633-2641.

110. Dodd, M.C. Potential impacts of disinfection processes on elimination and deactivation of antibiotic resistance genes during water and wastewater treatment. J. Environ. Monit. 2012; 14: 1754-1771.

111. Von Gunten, U. Ozonation of drinking water: Part II. Disinfection and by-product formation in presence of bromide iodide or chlorine. Water Res. 2003; 37: 1469-1487. 
112. Broadwater, W.T. Hoehn, R.C. and King, P.H. Sensitivity of three selected bacterial species to ozone. Appl. Microbiol. 1973; 26: 391-403.

113. Casolari, A. Physiological Models in Microbiology; Bazin M.J. and Prosser J.I. Eds.; CRC Press: Boca Raton. 1988 , FL II, 1-44.

114. Patil, S.; Valdramidis, V.P.; Karatzas, K.A.G.; Cullen, P.J.; Bourke, P. Assessing the microbial oxidative stress mechanism of ozone treatment through the responses of Escherichia coli mutants. J. Appl. Microbiol. 2011; 111: 136-144.

115. Xu, P.; Janex, M.L.; Savoye, P.; Cockx, A.; Lazarova, V. Wastewater disinfection by ozone: main parameters for process design. Water Res. 2002; 36: 1043-1055.

116. Patil, S.; Bourke, P.; Frías, J.M.; Kumar, T.B.; Cullen, P.J. Inactivation of Escherichia coli in orange juice using ozone. Innov. Food Sci. Emerging Technol. 2009; 10: 551-557.

117. Tang, K. W.; Dziallas, C.; Grossart, H.P. Zooplankton and aggregates as refuge for aquatic bacteria: protection from UV heat and ozone stresses used for water treatment. Environ. Microbiol. 2011; 13: 378-390.

118. Pak, G.; Salcedo, D.E.; Lee, H.; Oh, J.; Maeng, S.K.; Song, K.G.; Hong, S.W.; Kim, H.C.; Chandran, K.; et al. Comparison of antibiotic resistance removal efficiencies using ozone disinfection under different $\mathrm{pH}$ and suspended solids and humic substance concentrations. Environ. Sci. Technol. 2016; 50: 7590-7600.

119. Tseng, C.; Li, C. Ozone for Inactivation of Aerosolized Bacteriophages. Aerosol Science and Technology. 2006, 40, 683-689.

120. Cannon, J.L.; Kotwall, G.; Wang Qing. Inactivation of norovirus surrogates after exposure to atmospheric ozone. Ozone: Science and Engineering 2013; 35: 217-219. 